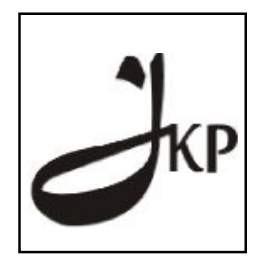

Info Artikel:

Diterima 06/06//2015

Direvisi 12/06/2015

Dipublikasikan 30/06/2015
Jurnal Konseling dan Pendidikan

ISSN Cetak: 2337-6740 - ISSN Online: 2337-6880

http://jurnal.konselingindonesia.com

Volume 3 Nomor 2, juni 2015, HIm 31-39
GHIIE

MULTIKARYA KONS

\title{
Peningkatan Perilaku Prososial Siswa di Sekolah melalui Layanan Bimbingan Kelompok dengan Teknik Modeling
}

Hastha Purna Putra, Nurhizrah Gistituati \& Syahniar

Universitas Negeri Padang

\section{Abstract}

The low prosocial behavior of students can inhibit the developmental tasks of adolescent such as the inability of appreciating others and getting others' respect. Group guidance can be used to improve students' prosocial behavior. The aim of this study was to reveal the effectiveness of group guidance service with modeling techniques in improving students' prosocial behavior. This quasi-experimental research with pretest and posttest control group design aims to find out whether group guidance services with modeling techniques can improve students' prosocial behavior or not. Two groups were selected by using purposive sampling. They were selected from Sekolah Menengah Pertama Islam Terpadu (SMPIT) Rabbi Radhiyya Curup Tengah and Madrasah Tsanawiyah Pesantren Muhammadiyah Curup Timur. Each group consisted of 10 students. There were five meetings of group guidance service for each experimental and control group. The data of prosocial behavior were collected by using pretest and posttest, then they were analyzed by using the Wilcoxon Signed Ranks Test and Kolmogorov-Smirnov Two Sample with SPSS version 16.00. The findings of this study were: (1) there was a significant difference between students' pretest and posttest of prosocial behavior in the experimental group, (2) there was a significant difference between students' pretest and posttest of prosocial behavior in the control group, (3) there was a significant difference between posttests of students' prosocial behavior in the experimental and the control group. Based on those findings, it is concluded that the students' prosocial behavior can be improved through group guidance with modeling techniques. Therefore, it is suggested for counseling teachers to do group guidance by using modeling techniques, especially in enhancing prosocial behavior and other social behaviors.

Keyword: Prosocial Behavior, Group Guidance Service and Modeling Technique

Copyright @ 2015 IICE - Multikarya Kons (Padang - Indonesia) dan IKI - Ikatan Konselor Indonesia - All Rights Reserved

Indonesian Institute for Counseling and Education (IICE) Multikarya Kons

\section{PENDAHULUAN}

Manusia sebagai makhluk sosial membutuhkan bantuan dari orang lain dan tidak dapat hidup sendiri, manusia akan saling berhubungan satu sama lain dalam lingkungannya. Lingkungan merupakan hal yang sangat penting dalam kehidupan manusia untuk mengembangkan keterampilan bersosialisasi, baik di lingkungan sekolah, lingkungan keluarga maupun lingkungan masyarakat. Lingkungan sosial yang dapat mendukung perkembangan individu secara positif, maka individu tersebut akan mencapai perkembangan sosialnya secara matang, termasuk di dalamnya perkembangan sosial remaja.

Remaja banyak yang menganut gaya hidup hedonis, yang membuat mereka hanya berpikir tentang kesenangan diri sendiri tanpa mau memikirkan keadaan orang lain. Remaja bukannya gemar untuk melakukan perilaku prososial, justru sebaliknya malah semakin banyak di antara remaja yang melakukan perilaku antisosial. Kecenderungan untuk melakukan perilaku prososial di antara remaja semakin menurun. Senada dengan hal tersebut, Hurlock (1999:210) mengungkapkan bahwa masa remaja erat hubungannya dengan nilai-nilai yang 
selaras dengan dunia orang dewasa yang akan dimasuki adalah tugas mengembangkan perilaku sosial yang bertanggung jawab. Salah satu dari perilaku sosial yang perlu dikembangkan adalah perilaku prososial.

Secara psikologis siswa Sekolah Lanjut Tingkat Pertama (SLTP) tengah memasuki tahapan perkembangan masa remaja. Masa remaja merupakan masa yang singkat dan sulit dalam perkembangan kehidupan manusia. Menurut Chaplin (2004:12), “Adolescence adalah periode antara pubertas dan kedewasaan, usia yang diperkirakan 12 sampai 21 tahun bagi anak perempuan yang lebih cepat matang dibandingkan anak laki-laki, antara 13 hingga 22 tahun bagi anak laki-laki”. Piaget (dalam Hurlock, 2004:206) mendefinisikan bahwa: Masa remaja adalah usia dimana anak-anak sudah tidak lagi merasa di bawah tingkat orang-orang yang lebih tua melainkan berada dalam tingkatan yang sama, sekurang-kurangnya dalam masalah hak.... Integrasi dalam masyarakat (dewasa) mempunyai banyak aspek afektif, kurang lebih berhubungan dengan masa puber....Termasuk juga perubahan intelektual yang mencolok.

Perubahan yang terjadi pada masa remaja tidak terlepas dari hakikat sekolah. Transisi dari sekolah dasar ke sekolah menengah memberikan pengalaman normatif yang membutuhkan proses adaptasi atau penyesuaian pada diri remaja. Salah satu tugas perkembangan remaja yang harus dicapai adalah berkaitan dengan hubungan sosial. Havighurst (dalam Syamsu Yusuf, 2006:74) mengemukakan tugas-tugas perkembangan sosial pada masa remaja yaitu: 1) mencapai hubungan sosial yang lebih matang dengan teman-teman sebaya, baik dengan teman sejenis maupun dengan lawan jenis, 2) mencapai peran sosial sebagai pria atau wanita artinya dapat menerima peranan masing-masing sesuai dengan ketentuan yang berlaku di masyarakat, 3) mencapai tingkah laku yang bertanggung jawab secara sosial yang berlaku di masyarakat.

Keberhasilan remaja dalam menyelesaikan tugas-tugas perkembangan di atas mengantarkannya ke dalam suatu kondisi berperilaku prososial yang baik, sehingga remaja yang bersangkutan dapat merasa bahagia, harmonis, dan dapat menjadi orang yang produktif. Namun sebaliknya apabila gagal, maka remaja akan mengalami ketidakbahagiaan atau kesulitan dalam kehidupannya. Oleh sebab itu, keberhasilan remaja ini menjadi tantangan bagi pihak sekolah, khususnya guru Bimbingan dan Konseling (BK) yang memberikan bantuan kepada siswa, sehingga siswa dapat memiliki perilaku prososial. Salah satunya adalah dengan cara memberikan suatu layanan bimbingan dan konseling yang bertujuan untuk meningkatkan perilaku prososial siswa.

Kurangnya kemampuan siswa dalam mengembangkan keterampilan bersosialisasi akan menunjukkan berbagai sikap negatif. Hal ini dapat menyebabkan terjadinya penyimpangan perilaku yang ditampilkan siswa di sekolah, seperti melanggar tata tertib sekolah, tidak mengerjakan tugas sekolah, tidak bisa bergaul, tidak bisa bekerjasama dan mengganggu teman. Rendahnya keterampilan siswa bersosialisasi dapat mengakibatkan konflik antar teman dan mengakibatkan perkelahian juga.

Apabila dibiarkan tanpa adanya penanganan khusus dari sekolah khususnya guru BK, maka akan berdampak pada kegagalan dalam mencapai tugas-tugas perkembangan individu. Individu yang kurang mampu mengembangkan keterampilan bersosialisasi berarti belum dapat menyelesaikan tugas perkembangan, untuk mencapai kematangan hubungan antar teman sebaya. Pencapaian tugas perkembangan pada individu merupakan keharusan karena mempengaruhi tahapan perkembangan selanjutnya. Bahkan dikhawatirkan akan menimbulkan konflik pada siswa.

Perilaku yang menimbulkan konflik tersebut termasuk perilaku antisosial. Perilaku antisosial secara formal disebut penyimpangan kepribadian yang antisosial (Antisocial Personality Disorder). Sama halnya kekerasan, agresi, perlakuan tidak senonoh serta perilaku kriminal lainnya di antara berbagai kelompok dalam masyarakat. Seringkali disertai dengan tidak adanya rasa bersalah dan penyesalan, dimana pelaku kurang peka terhadap kondisi emosi dan afeksinya (Sullivan, 2009:78). Perilaku tersebut adalah indikator bagi mereka yang perilaku prososialnya mengalami gangguan. Menurut Sullivan (2009:79) perilaku antisosial adalah kebalikan dari perilaku prososial. Banyak pakar yang beranggapan bahwa perilaku yang bersifat patologis adalah akibat dari proses keterasingan dari kehidupan wajar. Pembangunan yang terlalu berorientasi pada pertumbuhan ekonomi telah mengubah nilai hidup manusia menjadi pemburu materi dengan mengabaikan akibat sosial yang terjadi.

Permasalahan moral yang tumbuh dalam pribadi manusia adanya tarikan permanen antara upaya pemenuhan kepentingan diri pribadi dengan tuntutan untuk kesediaan dirinya memperhatikan kepentingan orang lain. Setiap individu cenderung mendahulukan kepentingan dirinya sendiri sebelum mengurus kebutuhan orang lain, namun tuntutan batiniahnya juga ada dorongan untuk membantu kesulitan orang lain (Imam Sutomo, 2008:43). Sebagaimana sabda Nabi Muhammad SAW dalam riwayat Muslim:

$$
\text { أخيــه }
$$


Artinya:

"Sesungguhnya Allah menolong seorang hamba selagi hamba tersebut menolong saudaranya".

Seberapapun banyaknya perilaku antisosial yang menjadi topik pembicaraan, tapi tetap ditemukan perilaku prososial yang dilakukan oleh seseorang di lingkungan sosialnya setiap hari. Namun yang ditemukan tidak sebesar antisosial. Adanya kecenderungan perilaku prososial yang rendah ditemui bahkan ada yang sangat rendah, sebagaimana dalam penelitian Erlina Permata Sari (2013:83) skor perilaku prososial dari 10 (sepuluh) orang siswa berada pada kategori sangat rendah 2 (dua) orang siswa, kategori rendah 8 (delapan) orang siswa dan tinggi 1 (satu) orang siswa.

Pertanyaannya adalah kenapa perilaku prososial yang harus dimaksimalkan? Perilaku prososial mencakup segala bentuk tindakan yang menguntungkan dan dilakukan untuk menolong orang lain, tanpa memperdulikan motif-motif penolong. Perilaku prososial bermanfaat bagi remaja dalam interaksi sosial mereka. Hal ini yang membuat perilaku prososial menjadi bagian atau norma sosial. Tiga norma yang paling penting di dalamnya adalah tanggung jawab sosial, timbal balik dan keadilan sosial (Sears, Freedman, dan Peplau,, 2005:50).

Perilaku prososial bagian dari kehidupan manusia sebagai makhluk sosial, dimana membutuhkan bantuan dari orang lain dan tidak dapat hidup sendiri, manusia akan saling berhubungan satu sama lain dalam lingkungannya. Lingkungan sosial yang dapat mendukung perkembangan individu secara positif. Maka remaja dalam berperilaku prososial yang baik, dituntut adanya kepekaan terhadap kondisi emosi dan afeksinya (Sullivan, 2009:78). Perilaku tersebut adalah indikator bagi mereka yang perilaku prososialnya mengalami gangguan. Menurut Sullivan (2009:79) perilaku antisosial adalah kebalikan dari perilaku prososial. Banyak pakar yang beranggapan bahwa perilaku yang bersifat patologis adalah akibat dari proses keterasingan dari kehidupan wajar.

Permasalahan moral yang tumbuh dalam pribadi manusia adanya tarikan permanen antara upaya pemenuhan kepentingan diri pribadi dengan tuntutan untuk kesediaan dirinya memperhatikan kepentingan orang lain. Setiap individu cenderung mendahulukan kepentingan dirinya sendiri sebelum mengurus kebutuhan orang lain, namun tuntutan batiniahnya juga ada dorongan untuk membantu kesulitan orang lain (Imam Sutomo, 2008:43).

Kecenderungan perilaku prososial yang bermasalah, dalam penelitian Erlina Permata Sari (2013:83) skor rata-rata perilaku prososial siswa $57,1 \%$, berada pada kategori rendah. Perilaku prososial mencakup segala bentuk tindakan yang menguntungkan dan dilakukan untuk menolong orang lain, tanpa memperdulikan motif-motif penolong. Perilaku prososial bermanfaat bagi remaja dalam interaksi sosial mereka. Hal ini yang membuat perilaku prososial menjadi bagian atau norma sosial. Tiga norma yang paling penting di dalamnya adalah tanggung jawab sosial, timbal balik dan keadilan sosial (Sears, Freedman, dan Peplau,, 2005:50).

Bagian dari rendahnya perilaku prososial tersebut tergambar dari hasil AUM (Alat Ungkap Masalah) Umum, dimana dari 50 siswa di SMPIT Rabbi Radhiyya Curup Tengah yang diberikan AUM Umum hanya 8 orang yang akan mengonsultasikan permasalahan yang dialami. Berarti hanya $16 \%$ saja siswa yang mau berbagi (sharing) dengan orang lain, sedangkan selebihnya 42 orang (84\%) tidak ingin berbagi dengan orang lain untuk mencari solusi dari permasalahan yang mereka alami.

Keluar dari permasalahan perilaku prososial yang merupakan tugas perkembangan sosial tersebut di atas, guru BK/ konselor dapat melakukan berbagai strategi pendekatan baik secara individual maupun kelompok. Sesuai dengan tujuan dari layanan bimbingan kelompok seperti yang dikemukakan oleh Prayitno (1995:178) adalah sebagai berikut:1) mampu berbicara di depan orang banyak, 2) mampu mengeluarkan pendapat, ide, saran, tanggapan, perasaan dan lain sebagainya kepada orang banyak, 3) belajar menghargai pendapat orang lain, 4) bertanggung jawab atas pendapat yang dikemukakannya, 5) mampu mengendalikan diri dan menahan emosi (gejolak kejiwaan yang bersifat negatif), 6) dapat bertenggang rasa, 7) menjadi akrab satu sama lainnya, 8) membahas masalah atau topik-topik umum yang dirasakan atau menjadi kepentingan bersama.

Maka adanya kesesuaian antara masalah perilaku prososial dengan solusi yang ditawarkan dari layanan bimbingan kelompok, dapat membantu para siswa keluar dari permasalahan perilaku prososialnya melalui layanan bimbingan kelompok. Layanan bimbingan kelompok yang diberikan, memanfaatkan dinamika kelompok dengan teknik modeling yang aktif dan topik-topik yang terkait dengan perilaku prososial. Pertimbangan terhadap dinamika kelompok yang aktif, akan menciptakan suasana yang hangat antara anggota kelompok, anggota kelompok saling berinteraksi, toleransi, saling menghargai pendapat, ide, gagasan, dan saran serta meningkatkan keberanian anggota kelompok untuk mengungkapkan buah pikirannya tanpa ragu, malu-malu bahkan takut. Hal inilah yang menjadi inti kajian dalam penelitian ini, yaitu peningkatan perilaku prososial siswa melalui layanan bimbingan kelompok dengan teknik modeling. 
Tujuan utama dalam penelitian ini adalah untuk mengungkapkan keefektifan layanan bimbingan kelompok dengan teknik modeling terhadap peningkatan perilaku prososial siswa SMPIT Rabbi Radhiyya Curup Tengah. Bagi Guru Bimbingan dan Konseling, penelitian ini dapat membantu dalam memberikan pelayanan bimbingan dan konseling terhadap siswa yang memiliki permasalahan dalam perilaku prososialnya.

\section{METODOLOGI PENELITIAN}

Desain penelitian yang digunakan dalam penelitian ini adalah penelitian eksperimen. Penelitian eksperimen adalah penelitian yang dilakukan dengan mengadakan manipulasi terhadap obyek penelitian serta diadakannya kontrol terhadap variabel tertentu (Iqbal Hasan, 2006:10). Eksperimen dalam penelitian ini adalah memberikan perlakuan layanan bimbingan kelompok kepada subjek penelitian.

Jenis desain eksperimen yang paling tepat untuk penelitian ini adalah Quasi Experiment atau eksperimen semu, yaitu suatu desain eksperimen yang memungkinkan peneliti mengendalikan variabel sebanyak mungkin dari situasi yang ada. Desain ini tidak mengendalikan variabel secara penuh seperti pada eksperimen sebenarnya, namun peneliti bisa memperhitungkan variabel apa saja yang tak mungkin dikendalikan. Salah satu dari desain yang tergolong quasi eksperimen adalah "Pretest Posttest Control Group Design". Desain ini merupakan desain eksperimen yang dilakukan dengan sebelum perlakuan diberikan dan sesudah perlakuan diberikan, dan juga terdapat kelompok eksperimen dan kelompok kontrol.

Populasi dalam penelitian ini adalah seluruh siswa kelas VIII SMPIT Rabbi Radhiyya Curup Tengah dan MTs Muhammadiyah Curup Timur yang terdiri dari 5 (lima) kelas, dengan jumlah siswa sebanyak 120 orang.

Penarikan sampel peneliti menggunakan purposive sampling dalam menentukan subjek penelitian adalah: (1) yang menjadi subyek penelitian hanyalah siswa yang memiliki skor prososial yang rendah dan sedang, (2) merupakan penelitian eksperimen dengan format kelompok dengan efektif anggota kelompok tidak lebih dari 15 orang. Di samping sampel tujuan juga ditetapkan sampel kuota yaitu mendasarkan pada jumlah yang ditentukan. Jumlah yang dimaksud adalah jumlah anggota kelompok yaitu sebanyak 10 orang siswa dalam satu kelompok. Memilih 10 orang siswa yang akan dijadikan sebagai sampel penelitian pada kelompok eksperimen dan juga kontrol dengan melihat hasil pretest yang memiliki skor menengah ke bawah (hingga sangat rendah), didasarkan dari masalah terberat dari hasil Alat Ungkap Masalah (AUM) Umum tingkat SLTP yang tidak mengonsultasikan masalahnya.

Teknik pengumpulan data yang digunakan dalam penelitian ini adalah melalui penyebaran instrumen skala prososial. Peneliti melakukan pengumpulan data penelitian dengan menggunakan instrumen skala prososial. Pengumpulan data dilakukan dengan pretest dan posttest yang diberikan kepada siswa di sekolah yang akan dijadikan sampel untuk kelompok eksperimen dan kelompok kontrol. Data yang diperoleh melalui sejumlah teknik pengumpulan data, yang dianalisis dengan menggunakan teknik dan rumus statistik non-parametrik. Teknik analisis data yang digunakan adalah statistik non parametrik, dengan menggunakan uji Wilcoxon Signed Ranks Test dan Kolmogorov Smirnov 2 Independent Sampels.

\section{HASIL PENELITIAN}

Hasil penelitian eksperimen yang telah dilaksanakan di kelas VIII SMPIT Rabbi Radhiyya Curup Tengah sebanyak 10 orang sebagai sampel kelompok eksperimen dan kelas VIII MTs Muhammadiyah Curup Timur sebanyak 10 orang sebagai kelompok kontrol. Data yang diperoleh adalah hasil pretest dan posttest berkaitan dengan perilaku prososial siswa. Instrumen perilaku prososial digunakan instrumen yang dikembangkan oleh peneliti sendiri. Berdasarkan data yang diperoleh peneliti, dapat dideskripsikan hasil penelitian sebagai berikut:

1. Hasil Pretest Kelompok Eksperimen dan Kelompok Kontrol

Hasil dari pembagian kelompok berdasarkan data yang didapatkan rata-rata tiap kelompok berada pada kategori rendah, sebagaimana terlihat pada tabel berikut:

Tabel 1:Distribusi Mean Tahap Pretest.

\begin{tabular}{|c|l|c|c|}
\hline \multicolumn{2}{|c|}{ Sampel } & N & $\begin{array}{c}\text { Mean } \\
\text { Perilaku Prososial }\end{array}$ \\
\hline \multirow{3}{*}{ Pretest } & Eksperimen & 10 & 89 \\
\cline { 2 - 4 } & Kontrol & 10 & 88 \\
\cline { 2 - 4 } & Total & 20 & \\
\hline
\end{tabular}


Data pada Tabel 1 di atas, dapat dilihat bahwa rata-rata skor pretest pada kelompok eksperimen sebesar 89 dan kelompok kontrol 88. Hal ini berarti menunjukkan bahwa kelompok ekperimen dan kelompok kontrol memiliki rata-rata perilaku prososial siswa yang sama.

2. Hasil Posttest Kelompok Eksperimen dan Kelompok Kontrol

Setelah pemberian layanan bimbingan kelompok dengan teknik modeling sebanyak 5 (lima) kali pertemuan kepada kelompok eksperimen selama 5 (lima) minggu dan tanpa teknik modeling untuk kelompok kontrol, kemudian peneliti mengukur tingkat perilaku prososial.

Adapun hasil pengukuran skala perilaku prososial pada kelompok eksperimen dan kontrol tersebut terdapat skor antara kelompok eksperimen dan kelompok kontrol. Apabila dilihat dari perbedaan rata-rata antara kelompok eksperimen setelah pemberian layanan bimbingan kelompok dengan teknik modeling, dengan kelompok kontrol setelah diberikan layanan bimbingan kelompok tanpa teknik modeling adalah sebagai berikut:

Tabel 2: Distribusi Mean Tahap Posttest

\begin{tabular}{|c|l|c|c|}
\hline \multicolumn{2}{|c|}{ Sampel } & N & \multicolumn{1}{c|}{$\begin{array}{c}\text { Mean } \\
\text { Perilaku Prososial }\end{array}$} \\
\hline \multirow{3}{*}{ Pretest } & Eksperimen & 10 & 124 \\
\cline { 2 - 4 } & Kontrol & 10 & 94 \\
\cline { 2 - 4 } & Total & 20 & \\
\hline
\end{tabular}

Data pada Tabel 2 di atas, dapat dilihat bahwa rata-rata pada kedua kelompok tidaklah sama, kelompok eksperimen perilaku prososial dengan skor 124 tergolong dalam kategori tinggi, sedangkan kelompok kontrol berada pada kategori rendah dengan skor 94.

3. Deskripsi Data Hasil Pretest dan Posttest Perilaku Prososial Kelompok Eksperimen

Untuk melihat perubahan tingkat perilaku prososial siswa pada kelompok eksperimen dari hasil pretest dan posttest. Pada saat pretest, siswa yang berada pada kategori sangat tinggi tidak ada (0\%) setelah diberi layanan bimbingan kelompok dengan teknik modeling menjadi 1 orang siswa (10\%), kategori tinggi sebelum diberi layanan bimbingan kelompok dengan teknik modeling tidak ada $(0 \%)$ setelah diberi layanan bimbingan kelompok dengn teknik modeling menjadi 3 orang siswa (30\%), adapun kategori sedang, sebelum diberi layanan bimbingan kelompok dengan teknik modeling 1 orang siswa (10\%) setelah diberi menjadi 3 orang siswa (30\%), dan siswa yang di awal memiliki perilaku prososial dengan kategori rendah ada 9 orang siswa setelah diberi layanan bimbingan kelompok dengan teknik modeling tidak ada lagi.

4. Deskripsi Data Hasil Pretest dan Posttest Perilaku Prososial Kelompok Kontrol

Data yang diperoleh diketahui terdapat perubahan yang tidak signifikan tingkat perilaku prososial siswa pada kelompok kontrol pada saat pretest dan posttest. Siswa yang pada saat pretest berada pada tingkat sangat tinggi, tinggi dan sangat rendah tidak ada $(0 \%)$, setelah diberi layanan bimbingan kelompok tanpa teknik modeling tetap tidak ada (0\%), kategori sedang di awal 1 orang siswa (10\%) menjadi 4 orang siswa (40\%), dan kategori rendah di awal 9 orang siswa (90\%) berkurang menjadi 6 orang siswa (20\%).

5. Pengujian Hipotesis

a. Pengujian Hipotesis Pertama

Hasil pengujian hipotesis pertama dapat dilihat pada tabel berikut:

Tabel 3: Hasil analisis Wilcoxon's Signed Ranks Test Kelompok Eksperimen.

\begin{tabular}{|l|l|}
\hline & Pretest - Posttest \\
\hline $\mathrm{Z}_{\mathrm{hitung}}$ & $-2.807 \mathrm{a}$ \\
\hline Signifikansi One Tailed & .0025 \\
\hline
\end{tabular}

Berdasarkan Tabel 3 di atas, terlihat bahwa angka probabilitas Asmyp. Sig.(1-tailed) perilaku prososial kelompok eksperimen sebesar 0,05, atau probabilitas sama dengan alpha 0,05 $(0,0025 \leq 0,05)$. Hasil tersebut menunjukkan bahwa Ho ditolak . Dengan demikian hipotesis pertama dalam penelitian ini dapat diterima, yaitu "terdapat perbedaan yang signifikan pada perilaku prososial siswa kelompok eksperimen sebelum dan setelah mendapat layanan bimbingan kelompok dengan teknik modeling." Maka terdapat peningkatan yang signifikan pada perilaku prososial siswa kelompok kontrol sebelum dan setelah mendapat bimbingan kelompok dengan teknik modeling, yaitu dengan rata-rata skor pretest 89 dengan kategori rendah dan posttest meningkat menjadi 124 dengan kategori tinggi. 
b. Pengujian Hipotesis Kedua

Hasil pengujian hipotesis kedua dapat dilihat pada tabel berikut:

Tabel 4: Hasil analisis Wilcoxon Signed Rank Test Kelompok Kontrol.

\begin{tabular}{|l|l|}
\hline & Pretest - Posttest \\
\hline$Z_{\text {hitung }}$ & $-2.572 \mathrm{a}$ \\
\hline Signifikansi One Tailed & .005 \\
\hline
\end{tabular}

Berdasarkan Tabel 4 menunjukkan nilai Asymp. Sig. sebesar 0.005. Hasil tersebut ditemukan bahwa nilai Asymp. Sig. hasil perhitungan lebih besar daripada nilai Asymp. Sig. pada tabel kritis $(0,005 \leq 0,05)$. Hasil tersebut menunjukkan bahwa Ho ditolak. Maka hipotesis kedua dalam penelitian ini dapat diterima, yaitu "terdapat perbedaan yang signifikan pada perilaku prososial siswa kelompok kontrol sebelum dan setelah mendapat layanan bimbingan kelompok tanpa teknik modeling." Maka terdapat peningkatan yang kurang signifikan pada perilaku prososial siswa kelompok kontrol sebelum dan setelah mendapat bimbingan kelompok tanpa teknik modelin, yaitu dengan rata-rata skor pretest 88 dengan kategori rendah dan posttest tetap berada pada kategori rendah dengan skor 94 .

c. Pengujian Hipotesis Ketiga

Hasil pengujian hipotesis dapat dilihat pada tabel berikut:

Tabel 5: Hasil Analisis Kolmogorov-Smirnov Kelompok Eksperimen dan Kontrol

\begin{tabular}{|l|l|}
\hline & $\begin{array}{l}\text { Posttest Perilaku } \\
\text { Prososial }\end{array}$ \\
\hline $\mathrm{Z}_{\text {hitung }}$ & 2.236 \\
\hline Signifikansi one tailed & .000 \\
\hline
\end{tabular}

Berdasarkan Tabel 5 di atas, dapat terlihat bahwa pada kolom Asymp.Sig. (1-tailed)/ signifikan untuk uji satu sisi adalah 0.000, atau probabilitas di atas $0.05(0.000 \leq 0.05)$. Maka H0 ditolak, ini berarti bahwa terdapat perbedaan yang signifikan perilaku prososial siswa kelompok eksperimen dengan siswa kelompok kontrol setelah mendapatkan layanan bimbingan kelompok dengan teknik modeling.Uraian tersebut menjawab hipotesis mayor yang berbunyi bahwa "Layanan bimbingan kelompok dengan teknik modeling efektif dalam meningkatkan perilaku prososial siswa".

\section{PEMBAHASAN}

Berdasarkan hasil pengujian hipotesis pertama yang berbunyi "Terdapat perbedaan yang signifikan pada perilaku prososial siswa kelompok eksperimen sebelum dan setelah diberikan perlakuan layanan bimbingan kelompok dengan teknik modeling." Berdasarkan data dapat diartikan perilaku prososial siswa meningkat setelah diberikan layanan bimbingan kelompok dengan teknik modeling.

Perilaku prososial siswa adalah hal yang penting dimiliki oleh siswa, oleh karenanya perlu suatu upaya untuk membantu siswa meningkatkan perilaku prososialnya. Layanan bimbingan kelompok adalah salah satu layanan dalam bimbingan dan konseling, dilakukan dengan teknik modeling terbukti efektif membantu meningkatkan perilaku prososial siswa. Hal ini dapat dilihat dimana hasil pretest yang menunjukkan bahwa tidak ada perbedaan yang signifikan, rata-rata antara kelompok eksperimen dan kelompok kontrol. Rata-rata tingkat perilaku prososial untuk kelompok eksperimen adalah 89, sedangkan pada kelompok kontrol rata-rata tingkat perilaku prososial sebesar 88. Ini berarti kedua kelompok sama-sama berada pada kategori rendah.

Setelah layanan bimbingan kelompok dengan teknik modeling diberikan kepada kelompok eksperimen, tingkat perilaku prososial siswa menjadi meningkat, yang mana semula berada pada kategori rendah, berubah menjadi kategori tinggi, sedangkan pada kelompok kontrol tidak ada perbedaan tetap berada pada kategori rendah. Dengan demikian perilaku prososial siswa itu bisa meningkat apabila didukung oleh beberapa faktor yang mana faktor tersebut berada disekitar siswa itu sendiri.

Melalui layanan bimbingan kelompok yang dilaksanakan lima sesi dengan topik-topik: (1) berbagi dengan orang lain untuk memecahkan masalah, (2) kerjasama dalam menggapai tujuan bersama, (3) menyumbang dan kedermawanan dengan keikhlasan, (4) menolong orang lain akan ditolong Allah, (5) kejujuran mengantarkan kepada kebaikan. Terbukti bahwa perilaku prososial akan lebih meningkat dengan adanya modeling dalam kehidupan sehari-harinya. Dalam penelitian ini layanan bimbingan kelompok dengan menggunakan model 
simbolik menjadikan siswa belajar untuk berprilaku prososial. Kenyataan di atas sesuai dengan pendapat Sprafkin (dalam Taylor, Freedmen, dan Peplau, 2012:464) bahwa belajar observasional dalam melihat model prososial juga penting seperti ditunjukkan dalam riset terhadap acara televisi prososial lebih banyak membantu. Modeling akan memberikan efek untuk meningkatkan perilaku prososial dalam berbagai situasi, maka anak yang sering melihat model yang melakukan perilaku prososial akan lebih mudah berperilaku prososial juga, baik dalam kehidupan nyata model sebenarnya maupun model simbolik dalam proses belajar.

Perilaku prososial dapat terjadi dimana saja dan kapan saja. Perilaku prososial juga akan terjadi di lingkungan sekolah. Kemampuan siswa dalam melakukan perilaku prososial antara siswa yang satu dengan siswa yang lain tidak sama. Siswa yang memiliki kemampuan perilaku prososial yang tinggi, dapat terlihat dari sikap yang senang akan membantu orang lain, memiliki kepedulian terhadap orang lain, berbagi dengan orang lain, peka terhadap keadaan sekitar, senang melakukan kerja sama dan memiliki kepribadian yang jujur. Sehingga akan mudah menjalani kehidupan sosial di lingkungannya dan ia tidak akan mengalami hambatan dalam mendapatkan bantuan dari orang lain. Sebaliknya siswa yang memiliki kemampuan perilaku prososial yang rendah akan mengalami hambatan dalam kehidupan sosialnya, dimana tidak memiliki tiga norma dalam kehidupannya, norma tanggung jawab sosial, norma timbal balik dan norma keadilan sosial (Sears, Freedman, dan Peplau, 2005:50). Maka masalah yang dialami oleh siswa tersebut yang berkaitan dengan perilaku prososial yang rendah memerlukan bantuan konselor.

Hipotesis kedua yang berbunyi "Terdapat perbedaan yang signifikan pada perilaku prososial siswa kelompok kontrol pada pretest dan posttest (layanan bimbingan kelompok tanpa teknik modeling)." Berdasarkan data tersebut dapat diasumsikan bahwa pada kelompok kontrol ada peningkatan tetapi kurang signifikan, terbukti tetap berada pada kategori rendah.

Sedangkan berdasarkan hasil pengujian hipotesis ketiga yang berbunyi "Terdapat perbedaan yang signifikan pada perilaku prososial siswa kelompok eksperimen yang diberikan layanan bimbingan kelompok dengan teknik modeling, dengan siswa kelompok kontrol yang diberikan layanan bimbingan kelompok tanpa teknik modeling". Ini berarti bahwa terdapat perbedaan yang signifikan antara perilaku prososial siswa kelompok eksperimen dan kelompok kontrol, setelah mendapatkan layanan bimbingan kelompok dengan teknik modeling dan tanpa modeling. Adanya perbedaan antara hasil pretest dan posttest pada kelompok eksperimen diduga sebagai akibat dari layanan bimbingan kelompok dengan teknik modeling yang diberikan. Menurut Prayitno dan Erman Amti (2004:108), bimbingan kelompok bertujuan secara khusus, diantaranya; 1) melatih siswa untuk dapat mengendalikan diri dalam kegiatan kelompok, 2) melatih siswa untuk dapat bersikap tenggang rasa dengan orang lain, 3) melatih siswa memperoleh keterampilan sosial dan 4) membantu siswa mengenali dan memahami dirinya dalam hubungannya dengan orang lain.

Menurut Prayitno (1995:23) dengan mengaktifkan dinamika kelompok memberikan kesempatan yang sama kepada anggota kelompok untuk berperan aktif mengeluarkan pendapat, berbicara secara terbuka, dapat mengembangkan kemampuan berkomunikasi dan dapat melatih pengendalian diri siswa, secara lebih khusus bimbingan kelompok bertujuan untuk mendorong pengembangan perasaan, pikiran, persepsi, wawasan dan sikap yang dapat meningkatkan penyesuaian sosial siswa, maka menggunakan model simbolik juga bertujuan untuk menghidupkan dinamika kelompok. Kesimpulan tersebut di atas mendukung pendapat Prayitno (1995:66) menyatakan bahwa bimbingan dan konseling kelompok dalam gerak dinamika kelompok dapat mengembangkan kemampuan sosial, berkepribadian mantap, keterampilan komunikasi efektif, sikap bertenggang rasa, memberi dan menerima toleran, bersikap demokratis dan memiliki tanggung jawab sosial dengan kemandirian yang kuat. Berdasarkan hasil analisis data di atas dapat disimpulkan bahwa layanan bimbingan kelompok dengan teknik modeling efektif dalam meningkatkan perilaku prososial siswa. Pendapat Agus Maemun (2012:2) bahwa Bimbingan kelompok dengan teknik modeling adalah suatu upaya bimbingan melalui kegiatan kelompok yang dilaksanakan dengan mengamati dan menghadirkan model secara langsung untuk mencapai tujuan bimbingan dan konseling, sehingga kecakapan-kecakapan pribadi atau sosial tertentu bisa diperoleh dengan mengamati dan mencontoh tingkah laku model-model yang ada.

Perry dan Furukawa (dalam Agus Maemun, 2012:2) menyatakan bahwa teknik modeling adalah suatu komponen dari suatu strategi dimana konselor menyediakan demonstrasi tentang tingkah laku yang menjadi tujuan. Taufik (2009:159) mengemukakan bahwa teknik modeling diberikan dengan cara klien mengamati orang lain sebagai model yang akan dicontoh. Kemudian klien diberi penguatan apabila mampu mencontoh model yang diberikan tersebut. Hal ini terutama dilakukan untuk memperoleh tingkah laku kecakapan sosial. 
Adapun hasil yang diperoleh dari pelaksanaan bimbingan kelompok dengan teknik modeling membuat siswa lebih termotivasi untuk lebih berperilaku prososial dengan membahas topik-topik prososial yang telah disaksikan dari model simbolik yang ditonton, sehingga menunjang terjadinya peningkatan perlaku prososial siswa.

\section{KESIMPULAN}

Berdasarkan data atau hasil penelitian yang diperoleh, setelah dilakukan analisis statistik, uji hipotesis dan pembahasan, maka dapat disimpulkan secara umum bahwa layanan bimbingan kelompok pada kelompok eksperimen maupun kontrol sama-sama signifikan adanya peningkatan antara pretes dengan posttest. Adapun bimbinghan kelompok teknik modeling lebih efektif dalam meningkatkan perilaku prososial siswa, dibanding tanpa teknik modeling. Terlihat dari skor perilaku prososial, dimana kelompok eksperimen pada awalnya secara rata-rata berada pada kategori rendah meningkat menjadi tinggi, adapun kelompok kontrol pada awalnya secara rata-rata berada pada kategori rendah tetap berada pada kategori rendah.

Berdasarkan hal tersebut di atas layanan bimbingan kelompok dengan teknik modeling lebih dapat meningkatkan perilaku prososial siswa dibandingkan tanpa teknik modeling. Layanan bimbingan kelompok yang bersifat aktif, dinamis, bebas, terbuka, meluas dan melibatkan siswa memungkinkan berkembangnya suasana kejiwaan yang sehat dengan spontanitas, sosialisasi yang baik, perasaan senang, empati, santai, dapat meningkatkan pemahaman, kesadaran diri, optimis serta dapat membuat sebuah komitmen untuk meningkatkan rasa percaya diri, rasa saling menghargai, empati, mampu bergaul dengan sesama dan yakin akan kemampuan yang dimiliki. Pada akhirnya diharapkan dapat memiliki perilaku prososial yang meningkat.

\section{SARAN}

Berdasarkan hasil penelitian, pembahasan, dan kesimpulan yang telah dikemukakan, ada beberapa saran yang dapat diajukan sebagai tindak lanjut penelitian ini. Beberapa saran yang dapat diajukan adalah sebegai berikut; 1) Bagi Guru BK/ Konselor, disarankan untuk mengadakan layanan bimbingan kelompok dengan teknik modeling di sekolah yang disertai dengan adanya inovasi. Layanan bimbingan kelompok dengan teknik modeling akan terlaksana secara intensif, bila terprogram secara terpadu dengan program sekolah, 2) Bagi Peserta Didik, setelah mengikuti bimbingan kelompok dengan teknik modeling siswa termotivasi, untuk meningkatkan perilaku prososialnya, juga mengembangkan sikap terbuka atau berbagi ketika ada masalah, belajar untuk berlaku jujur, peduli terhadap lingkungan sekitar dan membiasakan bekerjasama serta menolong orang lain, 3) Bagi Peneliti selanjutnya, direkomendasikan untuk menentukan variabel kontrol lainnya yang lebih banyak dan mempelajari aspek lain yang berkontribusi pada peningkatan perilaku prososial siswa melalui layanan bimbingan kelompok yang lebih kreatif dan inovatif.

\section{DAFTAR RUJUKAN}

Agus Maemun. 2012. Pengembangan Model Bimbingan Kelompok dengan Teknik Modeling untuk Mengembangkan Budi Pekerti Berbasis Nilai-Nilai Humanistik. Jurnal Bimbingan Konseling, (Online), Vol. 1, No. I, (http://journal.unnes.ac.id/sju/index.php/jubk, diakses 10 Desember 2013).

Chaplin, J. P. 2004. Kamus Lengkap Psikologi. Terjemahan oleh Kartini Kartono. Jakarta: Rajawali Press.

Erlina Permata Sari. 2013. Pengembangan Model Layanan Bimbingan Kelompok dengan Teknik Sosiodrama Untuk Meningkatkan Sikap Prososial. Jurnal Bimbingan Konseling, (Online), Vol. 2, No. II, (http://journal.unnes.ac.id/sju/index.php/jubk, diakses 9 Desember 2013).

Hurlock, Elizabeth B. 1999. Perkembangan Anak jilid II. Terjemahan oleh Med. Meitasari Tjandrasa. Jakarta: Erlangga.

Hurlock, Elizabeth B. 2004. Psikologi Perkembangan Suatu Pendekatan Rentang Kehidupan. Terjemahan oleh Istiwidayanti dan Soejarwo. Jakarta: Erlangga.

Imam Sutomo. 2008. Altruisme Dalam Kehidupan Masyarakat Plural (Studi Pemikiran Moral Nurcholish Madjid). Disertasi tidak diterbitkan. Yogyakarta: UIN Sunan Kalijaga.

Iqbal Hasan. 2006. Analisis Data Penelitian dengan Statistik. Jakarta: Bumi Aksara. 
Prayitno. 1995. Layanan Bimbingan dan Konseling Kelompok (Dasar dan Profil). Jakarta: Ghalia Indonesia.

Prayitno dan Erman Amti. 2004. Dasar-dasar Bimbingan Konseling. Cetakan Kedua. Jakarta: Rineka Cipta.

Prayitno. 2012. Jenis Layanan dan Kegiatan Pendukung Konseling (Pendidikan Profesi Konseling). Padang: FIP UNP.

Sears, D. O., Freedman, J. L., dan Peplau, L. A. 2005. Psikologi Sosial. Terjemahan oleh Michael Adryanto. Jakarta: Erlangga.

Sullivan, L. E. 2009. The Sage Glossary of the Social and Behavioral Sciences. Online Pub. Date: SAGE Publications, Inc.

Syamsu Yusuf. 2006. Psikologi Perkembangan Anak dan Remaja. Bandung: PT. Remaja Rosdakarya.

Taufik. 2009. Model-model Konseling. Padang: Fakultas Ilmu Pendidikan UNP.

Taylor, S. E., Peplau, L. A., dan Sears, D. O. 2012. Psikologi Sosial. Edisi Keduabelas. Terjemahan oleh Tri Wibowo B.S. Jakarta: Kencana Prenada Media Group. 